\title{
Operationalising ecosystem services in Europe
}

\author{
Mark D. A. Rounsevell ${ }^{1,2}$ (D) Marc J. Metzger $^{1} \cdot$ Ariane Walz $^{3}$
}

Received: 25 August 2019 / Accepted: 6 September 2019/Published online: 29 October 2019

(C) Springer-Verlag GmbH Germany, part of Springer Nature 2019

\section{Introduction}

Re-framing environmental resource use has led to the emergence of the ecosystem services (ES) concept, which explicitly acknowledges our dependence on nature and the need to better protect and manage natural resources (MA 2005; IPBES 2018; see Fig. 1). Although ES have been adopted in high-level policy frameworks - including the Convention on Biological Diversity and the EU Biodiversity Strategy - the application of the concept in policy and decision-making practice remains challenging (Saarikoski et al. 2018). Between 2012 and 2017, the European Commission funded the OPERAs project (Operationalising Ecosystem Research Applications) to explore how and under what conditions the ES concept can move beyond the academic domain towards practical implementation in support of sustainable decisionmaking and ecosystem management (Ainscough et al. 2019). OPERAs co-produced a diversity of approaches in twelve 'exemplar' case studies across a range of ecosystems (Patenaude et al. 2019; Schoonover et al. 2019; Walz et al. 2019): Swiss Alps, French Alps, Scotland, Barcelona, the Lower Danube, the Montado region, Dublin, Mediterranean agriculture, the Balearic islands, global, Pan-Europe and the wine sector (see Fig. 2). With a number of partners, OPERAs established the online, knowledge marketplace Oppla (www.oppla.eu) to improve and simplify how knowledge is

Mark D. A. Rounsevell

mark.rounsevell@ed.ac.uk

1 School of GeoSciences, The University of Edinburgh, Drummond Street, Edinburgh EH8 9XP, UK

2 Institute of Meteorology and Climate Research, Atmospheric Environmental Research (IMK-IFU), Karlsruhe Institute of Technology, Kreuzeckbahnstrasse 19, 82467 Garmisch-Partenkirchen, Germany

3 Institute of Environmental Science and Geography, Potsdam University, Potsdam, Germany created, obtained and shared ${ }^{1}$ for better environmental management. Here, we reflect on five key messages from the OPERAs project and how these messages are addressed within the articles of this Special Issue. Specifically, these articles:

1. Review and synthesise knowledge gaps, user needs and best practices (Lautenbach et al. 2019; Patenaude et al. 2019)

2. Increase knowledge and understanding to support policy and decision-making (Lee et al. 2019a; Liski et al. 2019a)

3. Improve and develop methods, tools and instruments to support ecosystem management (Liski et al. 2019a; Smith et al. 2019; Walz et al. 2019)

4. Co-develop and test these approaches in practice with stakeholders across a range of ecosystems in the 'exemplar' case studies (Liski et al. 2019b; Rosário et al. 2019; Walz et al. 2019)

5. Establish communities of practice (Metzger et al. 2019) and a marketplace for knowledge dissemination (the Oppla online platform; www.oppla.eu)

\section{Key message 1: Minimising damage to ecosystems and ensuring human well-being require effective integration of ecosystem services across policy sectors}

Minimising damage to ecosystems and ensuring the sustainable supply of essential ES for human well-being require integration at all levels of governance and across multiple policy sectors. At present, the level of integration of ES varies across policy sectors and governance levels and existing policy frameworks for ES remain far from optimal (IPBES 2018). Hence, further knowledge and guidance on how to integrate ES into policies were developed (Claret et al. 2018; Liski et al. 2019a). Several

\footnotetext{
${ }^{1}$ In collaboration with the FP7-funded OpenNESS project
} 


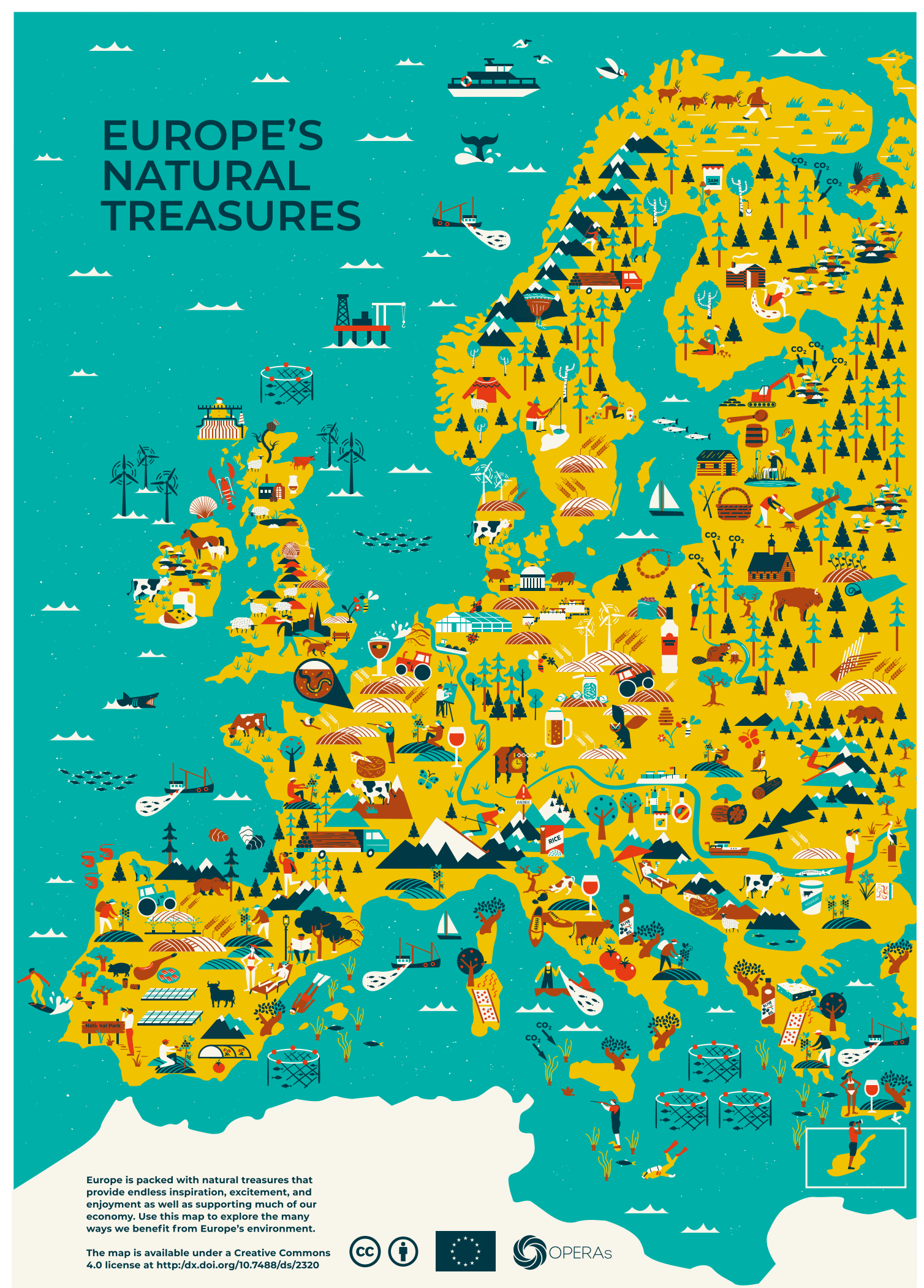

Fig. 1 Europe's natural treasures: a map of the distribution of ecosystem services in Europe (Metzger et al. 2018) (Available at https://doi.org/10.7488/ $\mathrm{ds} / 2320)$ 


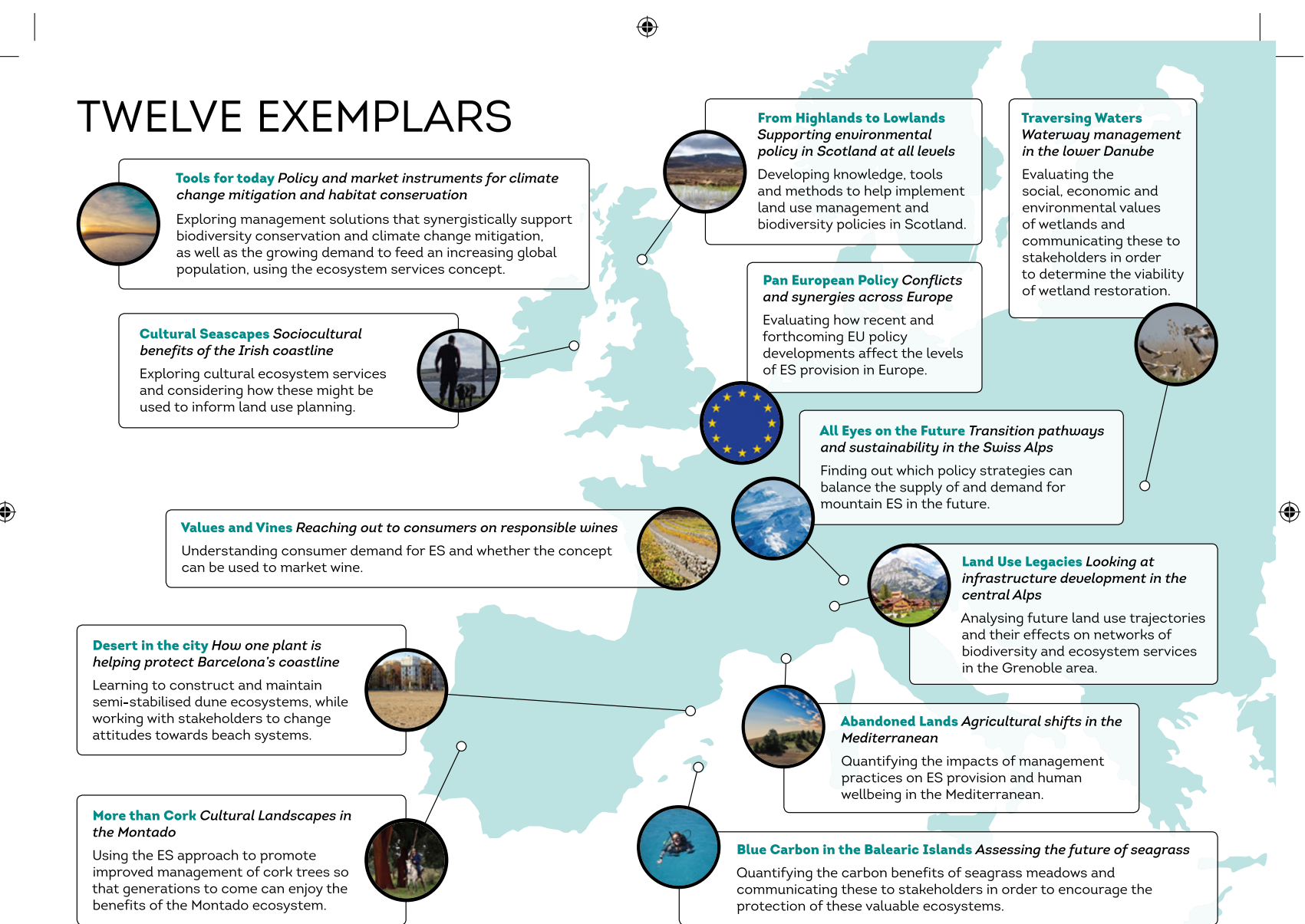

(1)

Fig. 2 The OPERAs 12 exemplar case studies used in the testing of ecosystem services tools, methods and instruments (source: Oppla, Countryscape)

policy initiatives provide opportunities for the effective integration of ES into sectoral policies, e.g. the green economy, resource efficiency roadmap, green infrastructure strategy and reform of environmentally harmful subsidies (Rounsevell and Metzger 2018). However, concrete policy instruments are essential to support the integration of ES in practice. Different types of policy instruments exist including information, decision support and implementation instruments (Mupepele and Dormann 2016; van Teeffelen et al. 2015; Wawrzyczek et al. 2018). For effective integration of ES in policy, more targeted actions and applications at all three instrument levels and at all levels of governance are necessary (Rounsevell and Metzger 2018). However, operational integration is generally lacking (Rounsevell and Metzger 2018), e.g. none of the EU policy sectors currently provides a comprehensive framework for the implementation and uptake of ES (IPBES 2018).

\section{Key message 2: It is important to understand what people value when developing ecosystem management plans}

Sustainable citizen behaviour is important for effective ecosystem conservation (Liski et al. 2019b; Schmidt et al. 2018). Decision-makers sometimes fail to engage with the public concerning the importance of ecosystems, and many people are unaware of the importance of conservation, or how it is relevant to them (Liski et al. 2019a). Successful public engagement depends on framing the topic in a way that everyone understands (Burton et al. 2019; Liski et al. 2019a; Rosário et al. 2019; Schmidt et al. 2016a, b). By highlighting the ES that people care about, decision-makers can adopt an approach that resonates with the public and shows potential mismatches with current ecosystem management (Schmidt et al. 2018). To achieve this, it is important 
to map and understand the values that a community places on its local ecosystems (Hernes and Metzger 2017; Liski et al. 2019b; Rosário et al. 2019).

A number of different methods can elicit values about ES (Koetse and Brouwer 2015; Liski et al. 2019a; Rosário et al. 2019; Schmidt et al. 2016a, b; Smith et al. 2019; Walz et al. 2019). Their selection depends on the circumstances and specific objectives of a study, including decision-making contexts, such as awareness raising, priority setting or the development of management and policy instruments (Schmidt et al. 2017, Rosário et al. 2019; Walz et al. 2019). Nonetheless, it is important to approach a study in a way that relates to key stakeholders (Liski et al. 2019a). This includes using language that resonates with stakeholders and framing issues for specific audiences (Liski et al. 2019b). Identifying different perspectives on ecosystem conservation can provide guidance for targeted information of use to local organisations in reaching a diverse set of stakeholders (Rosário et al. 2019). Policymakers can also use this insight to make decisions based on the values of a wider stakeholder community (Liski et al. 2019b; Schmidt et al. 2016a, b). These values are usually not immediately obvious, which is why it is so important to engage citizens in decision-making processes (Liski et al. 2019a). Accounting for ES demand can inform nature conservation goals and actions ('capacity effect'). Understanding demand can also influence decisions and reduce conflict ('constraint effect'). If supply of the service is low, but demand is high, managers can harness this demand to involve stakeholders in managing an ecosystem (Smith et al. 2019). However, if both demand and supply are low, awareness raising may be a more appropriate strategy.

\section{Key message 3: Traditional economic methods alone are insufficient to value the full benefits of ecosystem services; socio-cultural valuation can ensure a more comprehensive treatment of values}

Decision-makers can use various valuation methods to gain an understanding of the full implications of management decisions. This often involves assigning monetary values to environmental services (Koetse and Brouwer 2015; Smith et al. 2019). However, monetary valuation lends itself to certain ecosystems and services, to the exclusion of others. Social values and cultural services are particularly difficult to identify, monetise, quantify and explain and so are often ignored (Schmidt et al. 2016a, 2016b; Schmidt et al. 2017; Walz et al. 2019). Personal experience, social institutions and social interactions inform social values, which can be particularly important for certain groups and communities (Liski et al. 2019a, b). Social-cultural valuation (SCV) is a way of making these services, and the values associated with them, explicit. Taking account of these social preferences can help in making proposed management practices more widely accepted and with a greater chance of success (Walz et al. 2019). ES are a complex and unfamiliar concept for most people, and their role can be difficult to communicate or understand (Liski et al. 2019b). It is important to understand, therefore, what people value in the environment in order to communicate effectively, gain support for potential management schemes and reduce conflict (Liski et al. 2019a; Rosário et al. 2019). Many ES link to and depend on healthy ecosystem function, so cultural ES communicate the value of the whole ecosystem to people (Lee et al. 2019a). SCV is also important in helping stakeholders to engage with their environment and to understand their relationship with it (Walz et al. 2019). In this way, SCV can be utilised as a public consultation model to inform, for instance, green infrastructure planning (Derkzen et al. 2015; Schmidt et al. 2016a, b).

SCV must use a variety of methods in order to understand fully how and what people value in their environment (Walz et al. 2019). People relate most closely to cultural ES as these are experienced in the settings or situations in which people typically interact with nature and its benefits. Conversely, the value of regulating ES is less obvious or less well understood (Stürck et al. 2015). A number of SCV methods are available, can be used in combination and have been tested in practice for different decision purposes (Walz et al. 2019). Participatory mapping of ES and associated values helps people to connect their values to the landscape and to see the area as a whole (Lee et al. 2019a; Liski et al. 2019b; Schmidt et al. 2018). Decision-makers can also identify 'value hotspots' or areas where conflicts might arise. Deliberation allows people to develop their ideas through iterative discussion, building consensus and learning throughout the process. Choice experiments require people to think about what they value most using weighting or ranking techniques (Liski et al. 2019a). Visualisation tools can help people in better understanding the ES and landscapes in question (Lee et al. 2019a, Schmidt et al. 2016a, b, Schmidt et al. 2017). Scenario techniques encourage people to think about the sort of future they would like and what sort of management might help to achieve this (IPBES 2018; Lavorel et al. 2017; Burton et al. 2019).

\section{Key message 4: Land use decisions come with trade-offs over space and time and between stakeholders, but tools are available to help decision-makers to navigate trade-offs effectively}

Navigating trade-offs is an essential part of decision-making. It is particularly important in natural resource management where decisions made today may have implications for other ecosystems and future generations (IPBES 2018). To 
operationalise the ES concept and to manage natural capital wisely, decision-makers need to have a full understanding of the trade-offs associated with their decisions. If the increase in one ES happens directly or indirectly at the cost of another, maximising the provision of that service might lead to suboptimal results (Lee et al. 2019a). To support decisions, explicit information about trade-offs between ES is required and trade-off methods tested in practice (Walz et al. 2019). Different ES trade-offs exist between different ES categories. Some ES are more likely to lead to trade-offs rather than synergies, whilst others can be synergistic if well managed (Metzger et al. 2019). Regulating and cultural ES are more likely to have a synergistic relationship, whilst trade-offs are more common between regulating and provisioning services (IPBES 2018). Setting objectives for ES provision is often not straightforward, since the relationships between how much of a service is provided and the value it has for society are often non-linear (e.g. minimum levels needed to realise a benefit), location-dependent (pollination near crops, air purification near urban areas) and context-dependent (Lautenbach et al. 2019). Improvements are often possible compared to the current level of ES provision and business-as-usual scenarios.

Ecosystem management often requires choices to be made between different land use options and where to allocate funding (Lee et al. 2019a; Walz et al. 2019) and may use decision support tools to weigh up the trade-offs involved. A number of decision support tools deal with trade-offs explicitly by working with preferences or implicitly by quantifying the impacts of different decisions and comparing these against one another (Rounsevell and Metzger 2018) (see Table 1). Multifunctional landscapes provide a test bed to explore the many facets of ES trade-offs and synergies (Lee et al. 2019a). Research in the French Alps looked at whether services align spatially, i.e. form a 'bundle' (synergy), or not (trade-off) (Loucougaray et al. 2015; Walz et al. 2016), accounting for the spatial relationships associated with land cover or land management. However, multifunctional landscapes are not always a win-win situation; some trade-offs are unavoidable. Supply and demand trade-offs in Barcelona, the Swiss Alps and the Lower Danube explored the societal demand for ES and the ecosystem capacity to supply this demand (e.g. Brunner et al. 2015). Understanding trade-offs among beneficiaries is critical when changing boundary conditions or planning decisions affect the ES objectives of different groups of stakeholders (Rosário et al. 2019; Walz et al. 2019).

\section{Key message 5: There are many methods, approaches and tools to support ecosystem management, but applying them requires the sharing of real examples from which to learn best practice}

Despite their being a wealth of research on the subject of ES (Lautenbach et al. 2019), the principles of the concept do not always make it into practice, for a number of reasons. Knowledge gaps as well as practical obstacles can create bottlenecks (Lautenbach et al. 2019; Metzger et al. 2019). A lack of standardised research methods or reporting guidelines can make it difficult to compare projects, identify trends and make recommendations (Patenaude et al. 2019). This makes it difficult for decision-makers to know where to focus funding, which behaviours to encourage and how to give guidance on best practice (Rounsevell and Metzger 2018). There are now many tools and methods that have been tested in real-world situations, to support decision-making in applying the ES concept (Patenaude et al. 2019). However, tools and methods alone are not enough to encourage better ecosystem management. There is also a need to provide access to these tools and to foster their use through co-learning, knowledge exchange and applications in practice, which is achievable through active stakeholder dialogue (Patenaude et al. 2019; Schoonover et al. 2019) and more overarching communities of practice (Metzger et al. 2019). The OPERAs project worked with nine

Table 1 Examples of tools used to weigh up trade-offs in ecosystem management

\begin{tabular}{|c|c|c|}
\hline Name of tool & Purpose of tool & Further information \\
\hline $\begin{array}{l}\text { MCDA (multicriteria } \\
\text { decision analysis) }\end{array}$ & $\begin{array}{l}\text { To support decision-makers in choosing between alternative environmental management options } \\
\text { involving multiple actors }\end{array}$ & $\begin{array}{l}\text { https://oppla. } \\
\text { eu/product/2034 }\end{array}$ \\
\hline Streamline & A new format for semi-structured, one-on-one interviews in support of SCV & $\begin{array}{l}\text { https://oppla. } \\
\text { eu/product/1907 }\end{array}$ \\
\hline BackES & $\begin{array}{l}\text { A backcasting framework to develop and evaluate ES transition pathways and identify policy } \\
\text { interventions that increase ES benefits }\end{array}$ & $\begin{array}{l}\text { https://oppla. } \\
\text { eu/product/1905 }\end{array}$ \\
\hline TESSA & A toolkit for site-based ES assessment, especially in the water sector & $\begin{array}{l}\text { https://oppla. } \\
\text { eu/product } / 17590\end{array}$ \\
\hline ToSIA & A decision support tool that analyses sustainability impacts of value chains related to resource use & $\begin{array}{l}\text { https://oppla. } \\
\text { eu/product/1911 }\end{array}$ \\
\hline WeLCa & $\begin{array}{l}\text { A life-cycle, thinking-based software for calculation of impacts on ecosystem services in the wine } \\
\text { sector }\end{array}$ & $\begin{array}{l}\text { https://oppla. } \\
\text { eu/product/17473 }\end{array}$ \\
\hline
\end{tabular}


Scottish organisations to establish the ES Community Scotland (ESCom; http://escom.scot) (Metzger et al. 2019). With over 600 members, and regular events to bring together researchers, decision-makers and practitioners, ESCom illustrates how a community of practice can create space, align motivations and build trust (Metzger et al. 2019; Schoonover et al. 2019).

Providing free and ready access to ES tools, methods and practical examples of their application is also critical in operationalising ES for better ecosystem management. The Oppla information hub was developed with this purpose in mind (https://oppla.eu/). Oppla is an online knowledge marketplace; a place where the latest thinking on ES, natural capital and nature-based solutions is brought together. Its purpose is to simplify how we share, obtain and create knowledge to manage our environment in a better way. Oppla is an open platform that is designed for people with diverse needs and interests - from science, policy and practice; public, private and voluntary sectors; and organisations large and small, as well as individuals. Membership of Oppla is free and includes access to many online services. Ask-Oppla is a crowd-sourced enquiry service, where members of the Oppla community help to answer one another's questions. The Oppla Marketplace is a knowledge supermarket providing access to guidance, software, data and other useful resources, as well as promoting the outputs of individual projects or networks. As a not-for-profit company, Oppla also provides a legacy for the OPERAs project by continuing to engage with science, policy and practice into the future. It has also supported the Intergovernmental Science-Policy Platform on Biodiversity and Ecosystem Services (IPBES) in developing its web portal of policy support tools, thereby ensuring the widest possible access to ES knowledge worldwide (https://www.ipbes.net/policy-support/ about). The Oppla community and resource hub continues to grow and now (as at 17/6/2019) comprises over 2000 members and a 'knowledge marketplace' of more than 500 products and nearly 250 case studies from around the world.

\section{References}

Ainscough J, de Vries LA, Metzger MJ, Rounsevell MDA, Schröter M, Delbaere B, de Groot R, Staes J (2019) Navigating pluralism: understanding perceptions of the ecosystem services concept. Ecosyst Serv 36:100892. https://doi.org/10.1016/j.ecoser.2019.01.004

Brunner SH, Huber R, Grêt-Regamey A (2015) A backcasting approach for matching regional ecosystem services supply and demand. Environ Model Softw 75:439-458. https://doi.org/10.1016/j. envsoft.2015.10.018

Burton V, Metzger MJ, Brown C, Moseley D (2019) Green gold to wild woodlands; understanding stakeholder visions for woodland expansion in Scotland. Landsc Ecol 34:1693-1713. https://doi.org/10. 1007/s10980-018-0674-4
Claret C, Metzger MJ, Kettunen M, Ten Brink P (2018) Understanding the integration of ecosystem services and natural capital in Scottish policy. Environ Sci Policy 88:32-38. https://doi.org/10.1016/j. envsci.2018.05.019

Derkzen ML, van Teeffelen AJA, Verburg PH (2015) Quantifying urban ecosystem services based on high-resolution data of urban green space: an assessment for Rotterdam, the Netherlands. J Appl Ecol 52:1020-1032. https://doi.org/10.1111/1365-2664.12469

Hernes MI, Metzger MJ (2017) Understanding local community’s values, worldviews and perceptions in the Galloway and Southern Ayrshire Biosphere Reserve, Scotland. J Environ Manag 186:12-23. https:// doi.org/10.1016/j.jenvman.2016.10.040

IPBES (2018) The IPBES regional assessment report on biodiversity and ecosystem services for Europe and Central Asia, Rounsevell M, Fischer M, Torre-Marin Rando a, Mader a (eds). Secretariat of the Intergovernmental Science-Policy Platform on Biodiversity and Ecosystem services, Bonn, Germany, 892 pages

Koetse MJ, Brouwer R (2015) Reference dependence effects on WTA and WTP value functions and their disparity. Environ Resour Econ 65:723-745. https://doi.org/10.1007/s10640-015-9920-2

Lautenbach S, Mupepele A-C, Dormann CF, Lee H, Schmidt S, Scholte SSK, Seppelt R, van Teeffelen AJA, Verhagen W, Volk M (2019) Blind spots in ecosystem services research and implementation. Reg Environ Chang. https://doi.org/10.1007/s10113-018-1457-9

Lavorel S, Bayer A, Bondeau A, Lautenbach S, Ruiz-Frau A, Schulp N, Seppelt R, Verburg P, van Teeffelen A, Vannier C, Arneth A, Cramer W, Marba N (2017) Pathways to bridge the biophysical realism gap in ecosystem services mapping approaches. Ecol Indic 74:241-260. https://doi.org/10.1016/j.ecolind.2016.11.015

Lee H, Lautenbach S, Nieto APG, Bondeau A, Cramer W, Geijzendorfer IR (2019a) The impact of conservation farming practices on Mediterranean agro-ecosystem services provisioning - a meta-analysis. Reg Environ Chang. https://doi.org/10.1007/s10113-0181447-y

Lee H, Seo B, Koellner T, Lautenbach S (2019b) Mapping cultural ecosystem services 2.0 - potential and shortcomings from unlabelled crowd sourced images. Ecol Indic 96(1):505-515. https://doi.org/ 10.1016/j.ecolind.2018.08.035

Liski AH, Ambros P, Metzger MJ, Nicholas KA, Wilson AMW, Krause T (2019a) Governance and stakeholder perspectives of managed realignment: adapting to sea level rise in the Inner Forth estuary, Scotland. Regional Environmental Change. https://doi.org/10. 1007/s10113-019-01505-8

Liski AH, Koetse MJ, Metzger MJ (2019b) Addressing awareness gaps in environmental valuation: choice experiments with citizens in the Inner Forth, Scotland. Regional Environmental Change. https:// doi.org/10.1007/s10113-019-01505-8

Loucougaray G, Dobremez L, Gos P, Pauthenet Y, Nettier B, Lavorel S (2015) Assessing the effects of grassland management on forage production and environmental quality to identify paths to ecological intensification in mountain grasslands. Environ Manag 56(5):1039 1052. https://doi.org/10.1007/s00267-015-0550-9

MA (2005) Ecosystem and human well-being: synthesis report. Island Press, Washington,D.C

Metzger MJ, Gelfgren S, Allen K, Crofton A, Metzger M, Wilson C (2018) Europe's natural treasures - an illustrated ecosystem services map, [image]. The University of Edinburgh. https://doi.org/10.7488/ $\mathrm{ds} / 2320$

Metzger MJ, Dick J, Gardner A, Bellamy C, Blackstock K, Brown C, Chisholm R, Cochrane P, Drewitt J, Gimona A, Hester A, Mathieson S, Nijnik M, McVittie A, Petr M, Smith R, Smith M (2019) Knowledge sharing, problem solving and professional development in a Scottish Ecosystem Services Community of Practice. Reg Environ Chang. https://doi.org/10.1007/s10113-019-01537-0 
Mupepele AC, Dormann CF (2016) Environmental management: synthesize evidence to steer decisions. Nature 529(7587):466-466. https:// doi.org/10.1038/529466b

Patenaude G, Lautenbach S, Paterson JS, Locatelli T, Dormann CF, Metzger MJ, Walz A (2019) Breaking the ecosystem services glass ceiling: operationalising for impact. Reg Environ Chang. https://doi. org/10.1007/s10113-018-1434-3

Rosário IT, Rebelo R, Caser U, Vasconcelos L, Santos-Reis M (2019) Valuation of ecosystem services by stakeholders operating at different levels: insights from the Portuguese cultural montado landscape. Reg Environ Chang, https://doi.org/10.1007/s10113-019-01527-2

Rounsevell MDA, Metzger MJ (2018) OPERAs summary report - five years of ecosystem science for policy and practice 2012-2017. Zenodo. https://doi.org/10.5281/zenodo.3269668S

Saarikoski H, Primmer E, Saarela SR, Antunes P, Aszalós R, Baró F, Berry P, Blanko GG, Goméz-Baggethun E, Carvalho L, Dick J, Dunford R, Hanzu M, Harrison PA, Izakovicova Z, Kertész M, Kopperoinen L, Köhler B, Langemeyer J, Lapola D, Liquete C, Luque S, Mederly P, Niemelä J, Palomo I, Pastur GM, Peri PL, Preda E, Priess JA, Santos R, Schleyer C, Turkelboom F, Vadineanu A, Verheyden W, Vikström S, Young J (2018) Institutional challenges in putting ecosystem service knowledge in practice. Ecosystem Services 29:579-598. https://doi.org/10.1016/j. ecoser.2017.07.019

Schmidt K, Walz A, Jones I, Metzger MJ (2016a) The sociocultural value of upland regions in the vicinity of cities in comparison with urban green spaces. Mt Res Dev 36:465-474. https://doi.org/10.1659/ MRD-JOURNAL-D-16-00044.1

Schmidt K, Walz A, Martin-Lopez B, Sachse R (2017) Testing sociocultural valuation methods of ecosystem services to explain land use preferences. Ecosyst Serv 26:270-288. https://doi.org/10.1016/ j.ecoser.2017.07.001

Schmidt K, Martin-Lopez B, Julius E, Phillips PM, Makan N, Walz A (2018) Key landscape features in the provision of ecosystem services: insights for management. Land Use Policy 82:353-366. https://doi.org/10.1016/j.landusepol.2018.12.022
Schoonover HA, Grêt-Regamey A, Metzger MJ, Ruiz-Frau A, SantosReis M, Scholte SSK, Walz A, Nicholas KA (2019) Creating space, aligning motivations, and building trust: a practical framework for stakeholder engagement based on experience in 12 ecosystem services case studies. Ecol Soc 24(1):11. https://doi.org/10.5751/ES10061-240111

Smith GS, Brett H, Day BH, Bateman IJ (2019) Preference uncertainty as an explanation of anomalies in contingent valuation: coastal management in the UK. Regional Environmental Change. doi.org/10. 1007/s10113-019-01501-y

Stürck J, Schulp CJE, Verburg PH (2015) Spatio-temporal dynamics of regulating ecosystem services in Europe - the role of past and future land use change. Appl Geogr 63:121-135. https://doi.org/10.1016/j. apgeog.2015.06.009

Van Teeffelen A, Meller L, van Minnen J, Vermaat J, Cabeza M (2015) How climate proof is the European Union's biodiversity policy? Reg Environ Chang 15(6):997-1010. https://doi.org/10.1007/s10113014-0647-3

Walz A, Grêt-Regamey A, Lavorel S (2016) Social valuation of ecosystem services in mountain regions. Reg Environ Chang 16:19851987

Walz A, Schmidt K, Ruiz-Frau A, Nicholas KA, Bierry A, Aster de Vries L, Dyankov A, Joyce D, Liski AH, Marbà N, Rosário IT, Scholte SSK (2019) Sociocultural valuation of ecosystem services for operational ecosystem management: mapping amplications by decision contexts in Europe. Reg Environ Chang. https://doi.org/10.1007/ s10113-019-01506-7

Wawrzyczek J, Lindsay R, Metzger MJ, Quétier F (2018) The ecosystem approach in ecological impact assessment: lessons learned from wind farm developments on peatland in Scotland. Environ Impact Assess Rev 75:157-165. https://doi.org/10.1016/j.eiar.2018.05.011

Publisher's note Springer Nature remains neutral with regard to jurisdictional claims in published maps and institutional affiliations. 